\title{
MIXED SPECIES ASSOCIATIONS OF WHITE-TAILED AND MULE DEER IN SASKATCHEWAN
}

\section{by Richard S. Miller, Department of Biology, University of Saskatchewan}

Last October, about 10 miles north of Carrot River, I and two companions saw five antlerless deer feeding in an open meadow just off the road we were driving on. Disturbed by our car the deer fled as a group into the bush, crossing the road in plain view about 50 yards in front of the car. Four were Whitetailed Deer (Odocoileus virginianus) and one a Mule Deer (O. hemonius). They were easily identifiable by their external characters and by the way they moved, but they fed as a group and fled as a group until they reached the bush. At the edge of the trees, the Mule Deer typically stopped in the open for a last look before entering cover, while the White-tails entered the trees and then stopped.

Both species are known to occur together in many parts of the province and there is ample opportunity for this type of association to occur. It is, nevertheless, unusual for these two species to show this kind of mixed species behaviour. The author would be interested to learn of other observations of Mule Deer and White-tailed Deer associations in Saskatchewan.

\section{The Plains Grizzly Success story in Wildlife Conservation}

\section{by Stephanie Stewart, Moose Jaw}

We are so frequently confronted with evidence of man's destructiveness and lack of forethought in the use of his natural surroundings and those who preach conservation so often feel themselves to be voices "crying in the wilderness" that it was encouraging to come across the story of an effort to preserve what remains of a once mighty race in Western American wildlife-that fabled giant the Plains Grizzly (Ursus horribilis horribilis).

Great credit is due the Alberta Government, the oil industry (whose seismic crews first penetrated what proved to be the grizzly's last stronghold) and particularly to $\mathrm{Mr}$. Albert Oeming of Edmonton, for preserving and protecting what remains of the great Plains Grizzlies, until recently thought to have succumbed to man's encroachment upon its natural domain.
The buffalo that once roamed the western plains no longer exist free in nature; they live in national parks, managed as a curiosity and tcurist attraction, but at least they have been saved from extinction and can perpetuate their kind. Until recently it was thought that the great Plains Grizzly had not been so fortunate, but in 1935 Bella Twin, an Indian woman working her trapline in the wilderness of northern Alberta, shot a bear. There was nothing remarkable in this except that the bear was later estimated to have weighed half a ton, and Bella Twin (who was interested in beaver, and to whom the bear was merely incidental) shot it with a .22 rifle. It took her eight shots. Bella Twin skinned the bear, and two weeks later presented it along with her bcaver belts at the village of Slave Lake, and here the bear skin aroused no little curiosity. It particularly aroused the curiosity of Rheinhold Eben, top guide and huniter of the district, who securing directions from Bella managed to locate the skull, and measuring it, 